\title{
Woody charcoal with traces of pre-charring decay from the Late Oligocene (Chattian) of Norken (Westerwald, Rhineland-Palatinate, W Germany)
}

\author{
DIETER UHL ${ }^{1,2^{*}}$, MICHAEL WUTTKE ${ }^{1}$ and ANDRÉ JASPER ${ }^{2}$ \\ ${ }^{1}$ Senckenberg Forschungsinstitut und Naturmuseum, Senckenberganlage 25, 60325 Frankfurt am Main, \\ Germany; e-mails: dieter.uhl@senckenberg.de, michael.wuttke@senckenberg.de \\ ${ }^{2}$ Programa de Pós-Graduação em Ambiente e Desenvolvimento, Universidade do Vale do Taquari - UNIVATES \\ (PPGAD/UNIVATES), Lajeado, Rio Grande do Sul, Brazil; e-mail: ajasper@univates.br
}

Received 2 October 2019; accepted for publication 12 March 2020

\begin{abstract}
A variety of traces of pre-charring decay are described from coniferous charcoals from the Norken locality, stratigraphically positioned within the Breitscheid Formation (Late Oligocene, Chattian) of the Westerwald area (Rhineland-Palatinate; W Germany). The traces include three-dimensionally preserved as well as collapsed fungal hyphae, collapsed filamentous structures (maybe related to ascomycetes), so-called shot-like holes of different diameters in cell walls of tracheids, as well as crater-like structures on the surface of tracheid walls. The latter occur on tracheids with bordered pits, in the direct vicinity of charred phloem (so far only rarely reported from pre-Quaternary charcoal). These observations, together with evidence that some of the charcoal fragments originated from wood that dried out prior to charring, point to a surface fire as the most likely source of the charcoal, although it cannot totally be ruled out that (partly) dead but still standing trees were affected during a crown fire. The data from the Late Oligocene of Norken provide further evidence that pre-Quaternary charcoal can be used as an additional, so far largely underutilized source for additional information about plantmicroorganism interactions in deep time.
\end{abstract}

KEYWORDS: Late Oligocene, charcoal, palaeowildfire, fungi, ascomycetes

\section{INTRODUCTION}

Fossil charcoal is an excellent source of information about a number of palaeoenvironmental parameters reaching back as far as the Palaeozoic (e.g. Scott, 2000). Besides providing unequivocal evidence for the occurrence of wildfires in palaeoecosystems, it is also possible to obtain information about the types of such wildfires (i.e. ground, surface or crown fire), as well as certain environmental parameters which can be deduced from specific modifications of plant anatomy (e.g. growth rings in wood due to seasonality) (e.g. Scott, 2000, 2010; Scott et al.,

\footnotetext{
Corresponding author
}

2014). Recently, El Atfy et al. (2019) demonstrated that pre-Quaternary charcoal from clastic sediments can also be used to obtain information about pre-charring plant-microbe interactions. They provided a first general overview of pre-charring decay-related modifications of cell walls that have been observed in pre-Quaternary charcoal from a number of different localities from the Permian up to the Palaeogene. The same had previously been demonstrated for charcoal from archaeological contexts (e.g. Moskal-del Hoyo et al., 2010).

El Atfy et al. (2019) figured and described socalled shot-like holes produced by fungal hyphae 
penetrating cell walls, from the Late Oligocene Norken locality, as an example of such structures, which are usually associated with brown rot in modern wood (e.g. Schweingruber, 1990; Schweingruber et al., 2006; Schwarze, 2007). However, the spectrum of decay-related modifications of cell walls seen in fossil charcoal from this locality is much more diverse. As the potential of pre-Quaternary charcoal (especially from clastic sediments) as a source of information on plant-microbe interactions is so far largely unexplored, the charcoal from Norken has subsequently been analysed in greater detail regarding such decay-related structures. The present contribution provides an in-depth analysis of the whole spectrum of these structures observed so far, delivering a more complete picture of plant-microbe interactions observed in charcoal from this locality.

\section{GEOLOGY, PALAEONTOLOGY AND STRATIGRAPHY}

The village of Norken is located at the western border of the High Westerwald (Fig. 1). This region is part of the Rhenish Slate Mountains, which were formed during the Variscan Orogeny during the late Palaeozoic. After the Variscan Orogeny until the beginning of the Cenozoic, the Devonian rocks from this region experienced intensive weathering and erosion (Baumann, 1993). During the Oligocene the area was subject to tectonic upheavals, resulting in the formation of numerous depressions, small basins and tectonic graben structures, which were subsequently filled with up to $100 \mathrm{~m}$ thick, purely continental sediments, including claystones, black pelites ("oilshales") and fossil-rich lignites (e.g. Schäfer et al., 2011; Uhl et al., 2011). There was also intensive volcanism in this area during the Oligocene, which led to the deposition of massive basaltic tuff/tuffite deposits, as well as basalt sheets (e.g. Schäfer et al., 2011). The maar or crater lake of Enspel, with its renowned fossil-rich deposits (e.g. Poschmann et al., 2010; Köhler and Uhl, 2014; Uhl and Poschmann, 2018), is also related to this volcanism (Schindler and Wuttke, 2010, 2015).

The fossil-bearing deposits from Norken can be assigned to the Breitscheid Formation (cf. Uhl et al., 2011). This formation is of Late Oligocene (Chattian) age and consists of tuffs,

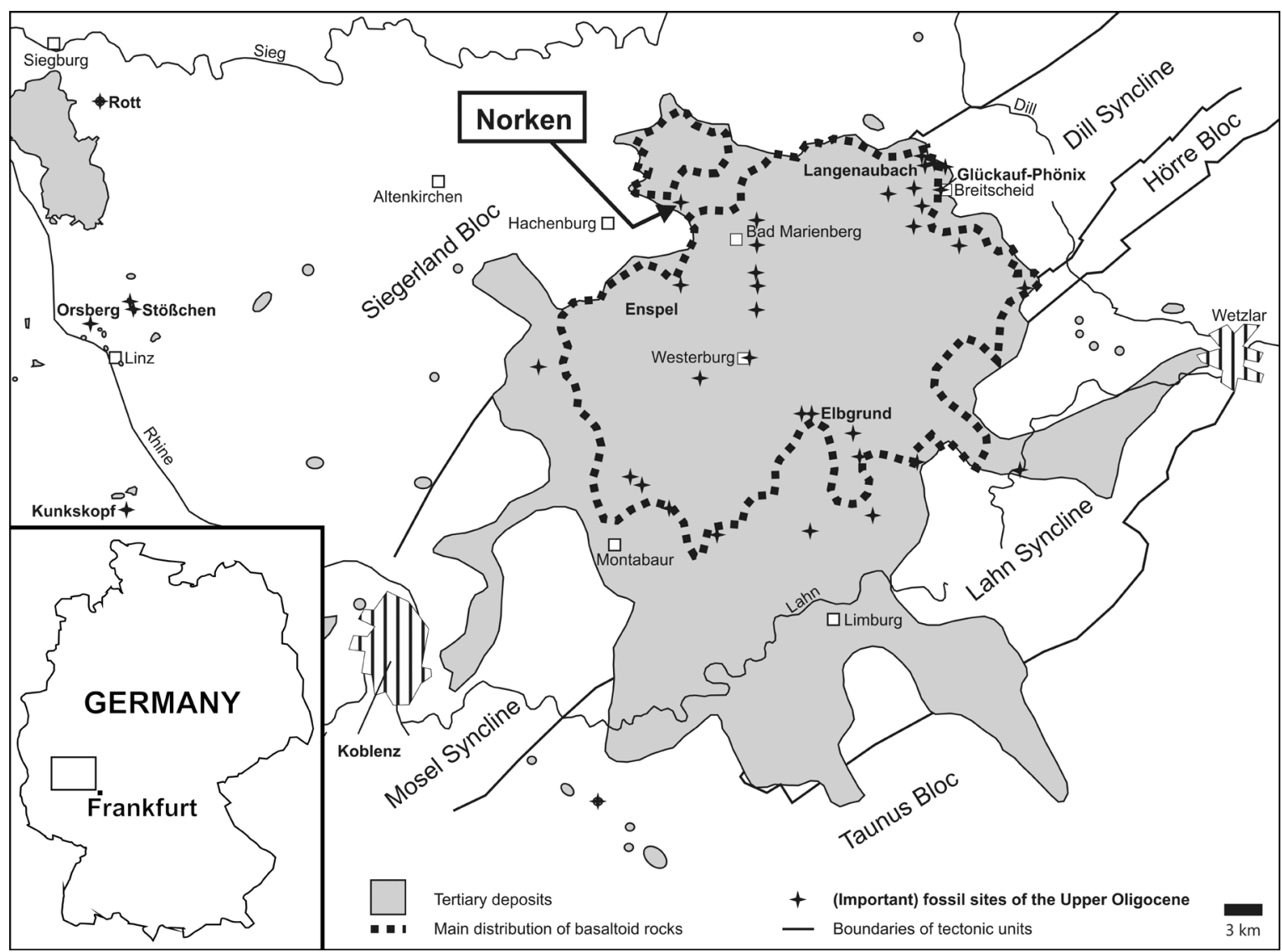

Fig. 1. Geological overview map of the Westerwald Tertiary; + fossil localities (after Schindler and Wuttke, 2010) 
tuffites, siliciclastic deposits as well as lignites (e.g. Schäfer et al., 2011). The Breitscheid Formation includes three so-called "main lignite seams", of which only the uppermost seam has been mined in Norken (Steckhan, 1973). At this locality this seam overlies lacustrine sediments consisting of fine-grained, laminated black pelites, as well as coarse re-sediments probably originating from the banks of the lake (Uhl et al., 2011).

The macroflora from Norken represents a riparian forest dominated by Acer tricuspidatum Bronn and Glyptostrobus europaeus (Brongniart) Unger, with only rare constituents from other vegetation types (Müller, 1997; Uhl et al., 2011, 2018; Krüger et al., 2017). Fossil charcoal from Norken, assignable to taxodioid Cupressaceae, provided unequivocal proof of the occurrence of palaeowildfires at this locality during the Late Oligocene (Uhl et al., 2011).

For more details on the geology and palaeontology of the Norken locality, see Steckhan (1973), Uhl et al. (2011, 2018) and Krüger et al. (2017).

\section{MATERIAL AND METHODS}

The material analysed here has been collected from spoil tips of the former Späth lignite mine in Norken in Westerwald, W Germany (Fig. 1). Samples are stored in the collection of the Maarmuseum Manderscheid (Germany), under collection numbers MMM-2012-001 to -198 .

For SEM analysis, small pieces of charcoal, which is rather rare at this locality, were mechanically extracted from lignite samples with the aid of preparation needles and tweezers under a binocular microscope (Leica M80). Samples were mounted on standard stubs with liquid LeitC (Plano, Münster, Germany), gold-coated, and subsequently examined with a JEOL JSM 6490 LV scanning electron microscope (SEM; accelerator current $20 \mathrm{kV}$ ) at the Senckenberg Forschungsinstitut und Naturmuseum Frankfurt, Germany, for further analysis. Two of the seven charcoal samples analysed showed evidence of pre-charring decay.

\section{RESULTS}

Macroscopically the specimens from Norken exhibit a silky lustre and a black streak, as well as excellent three-dimensional preservation and homogenized cell walls (Pl. 1,2) when analysed by SEM. Together these features are regarded as typical for charcoal (e.g. Scott, 2000, 2010). "Checking" of cell walls occurs in some specimens (Pl. 1, fig. 1).
Fungal hyphae can be observed in several specimens (Pl. 1, figs 2-6). Most abundant are three-dimensionally preserved hyphae with a smooth surface and diameter of $~ 1.0$ 1.3 (1.6) $\mu \mathrm{m}$ (Pl. 1, figs 2-4). In a single case, a three-dimensionally preserved hypha of comparable dimensions but with a granulated surface could be observed (Pl. 1, fig. 6). Besides three-dimensionally preserved smooth hyphae, collapsed hyphae with a smooth surface also occur. In some cases it was possible to observe a transition from three-dimensional to collapsed hyphae which seem to be fused to the cell wall (Pl. 1, fig. 4). Based on the size it seems likely that these hyphae were produced by "higher" fungi. However, as no clamp-connections have been observed in the charred hyphae, an unequivocal affiliation to basidiomycetes is not possible. Besides these hyphae, smaller collapsed filamentous structures also occur (Pl. 2, fig. 3); they may be remnants of either ascomycetes or filamentous bacteria. Some of the smooth threedimensionally preserved hyphae grew through shot-like holes in the cell walls of tracheids (Pl. 1, figs 1-4). In one case, two of these hyphae seem to have penetrated the wall through a single hole (Pl. 1, fig. 4). In the cases where hyphae could be observed crossing the cell wall through the shot-like holes, the entrances of these holes were widened in crater-like structures (Pl. 1, figs 3,4). Besides the shot-like holes associated with fungal hyphae, there were other shot-like holes that were considerably smaller: $\sim 0.8-$ $1.0 \mu \mathrm{m}$ in diameter (Pl. 1, figs 3-6). Although no direct connection could be observed, it seems possible that these holes were produced by the same organisms that produced the small filamentous structures. An additional feature of the charcoal from Norken, probably related to microbial decay prior to charring, are craterlike structures of different diameters on tracheid walls. One type of these structures, ranging in diameter from 2.0 to $3.5 \mu \mathrm{m}$, is related to the large shot-like holes mentioned above ( $\mathrm{Pl} .1$, figs 3-5). A second type of crater-like structure is much flatter and wider $(12-18 \mu \mathrm{m})$ than the structures directly related to shot-like holes. It occurs abundantly on some of the tracheids (Pl. 2, figs 1-4) and in one case a filamentous structure can be seen growing over the surface of such a crater-like structure (Pl. 2, fig. 3).

Another interesting observation, although not directly related to microbial decay, is the presence of phloem in one charcoal specimen 

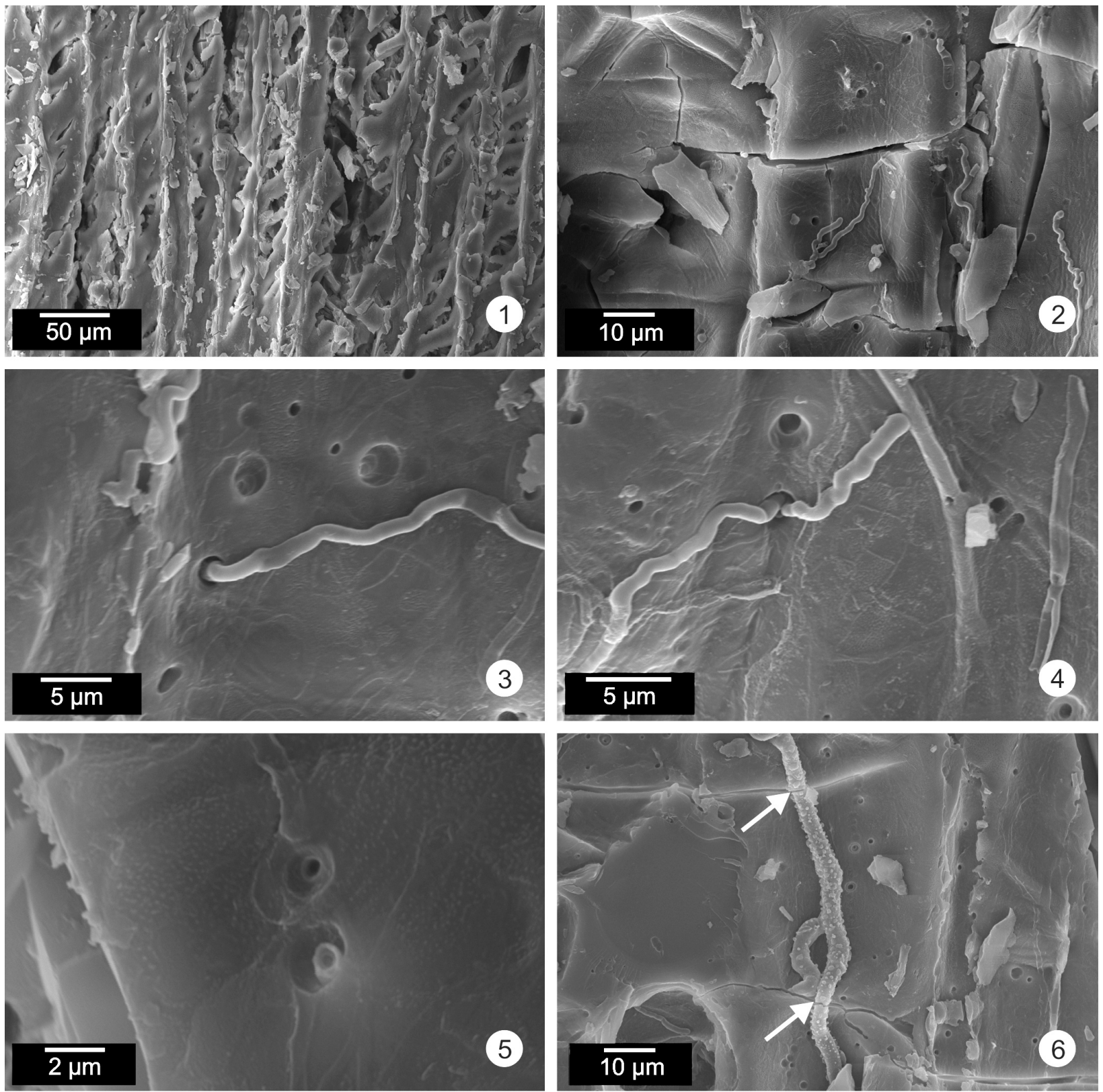

Plate 1. SEM images of woody charcoal from the Late Oligocene of Norken (MMM-2012-138). 1. Tracheids exhibiting "checking" of the cell walls, indicative of drying out prior to charring (cf. Jones, 1993); 2. Overview of tracheids with three-dimensionally preserved fungal hyphae and shot-like holes (modified from El Atfy et al. 2019); 3. Detail of tracheid wall with shot-like holes of different diameters, as well a fungal hypha growing through a shot-like hole (modified from El Atfy et al., 2019); 4. Detail of tracheid wall with shot-like holes of different diameters, as well as two fungal hyphae growing through a single shot-like hole; arrow points to transition from three-dimensionally preservation to the collapsed state of a fungal hypha (modified from El Atfy et al., 2019); 5. Details of shot-like holes, with crater-like structures around holes (modified from El Atfy et al., 2019); 6. Tracheid with shot-like holes and a granulated fungal hypha. Arrows point to parallel cracks in the cell wall and the hyphae

(Pl. 2, figs 5, 6). The phloem, located in the direct vicinity of areas exhibiting the flat craterlike structures in the tracheid walls, consists of sieve cells with sieve pores in the radial cell walls, as well as axial parenchyma (Pl. 2, fig. 6). So far, the published record of phloem preserved in charcoal is rather limited, with only a few records (e.g. Degani-Schmidt et al., 2015). It is noteworthy that the crater-like structures seen on tracheid walls of the charcoal from Norken occur mostly in an area located between these phloem cells and normal tracheids with bordered pits. Unfortunately it is not possible to identify fibers associated with phloem, due to the fragmentary preservation of the charcoal.

\section{DISCUSSION}

The observable anatomical features (e.g. homoxylic wood) of the charcoal from Norken analysed for this study point to a gymnospermic, 

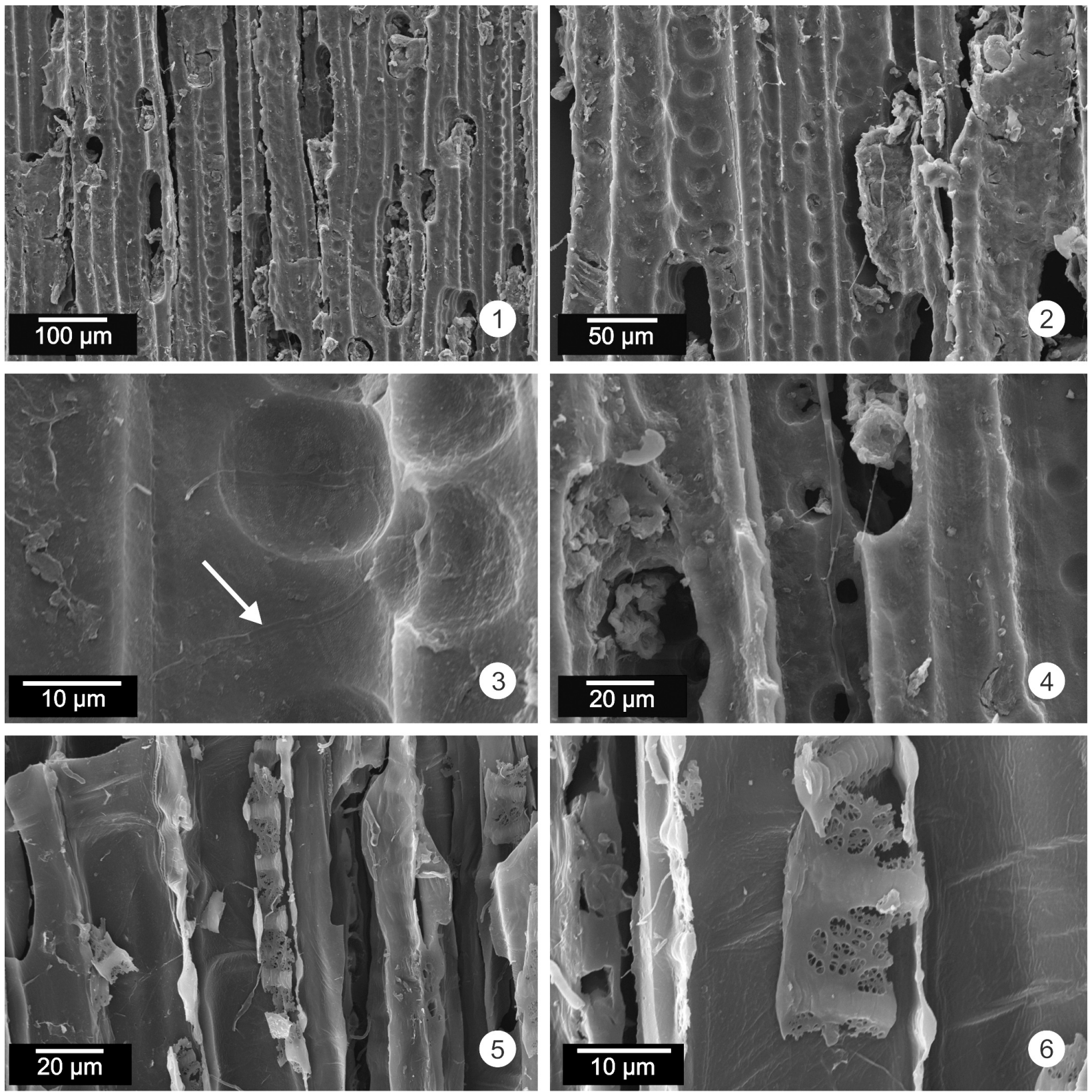

Plate 2. SEM images of woody charcoal from the Late Oligocene of Norken (MMM-2012-139). 1. Overview of charred wood with numerous crater-like structures on cell wall surfaces; 2 . Detail of $1 ; \mathbf{3}$. Close-up of crater-like structures on cell walls, with collapsed filamentous structure (arrow); 4. Tracheid with slightly degraded bordered pits next to area with crater-like structures on cell walls; $\mathbf{5}$. Overview of charred phloem (sieve cells and axial parenchyma) of the same specimen as shown in $1-4 ; 6$. Detail of sieve pores from 5

probably coniferous origin of the wood, similar to charcoal with an affinity to taxodioid Cupressaceae studied by Uhl et al. (2011) from this locality. Due to the small size of the fragments and the fact that some delicate but taxonomically important anatomical details (e.g. crossfield pitting) can be distorted during charring (cf. Gerards et al., 2007), it is not possible to provide a more specific taxonomic assignment for this material.

In some of the charcoal specimens, remnants of microbes (higher fungi, ascomycetes and/or filamentous bacteria) as well as modifications of the cell walls occur, which are interpreted as evidence of pre-charring microbial decay, can be observed.

The most conspicuous evidence consists of three-dimensionally preserved and collapsed hyphae, as well as smaller filaments, which provide direct evidence for the occurrence of higher fungi, as well ascomycetes and/or filamentous bacteria. However, the question arises as to whether these structures, especially the threedimensionally preserved hyphae, are in fact fossil hyphae or modern contamination. There are a number of arguments to support the 
interpretation of these remains as fossil hyphae that were present prior to charring. (1) Besides the fossil charcoal, a number of uncharred plant remains from Norken have been analysed by SEM (e.g. Uhl et al., 2018; unpublished data), and in none of these remains was any evidence of comparable modern fungi or other microbes observed. (2) The charcoal specimen with three-dimensionally preserved hyphae exhibits numerous cracks in the cell walls due to compression of sediments (e.g. Pl. 1, figs 2, 6), and in cases where hyphae are crossing these cracks the hyphae are also broken (Pl. 1, fig. 6). In the case of modern fungi colonizing charcoal, hyphae would simply cross such cracks in the cell walls. (3) In some places, transitions from three-dimensional hyphae to collapsed hyphae, which seem to be fused to the cell walls, can be observed. Such collapsed hyphae, probably fused to the cell wall, are typical for fossil hyphae occurring in pre-Quaternary fossil charcoal (e.g. Uhl et al., 2007; Kubik et al., 2015; Jasper et al., 2017; El Atfy et al., 2019). (4) As the chemical structure of the compounds of a typical plant cell wall (i.e. cellulose, hemicellulose, pectin and lignin) is destroyed during charring, ultimately leading to cell walls consisting of almost pure carbon, charcoal can be considered to be mostly inert in terms of chemical or biological destruction (e.g. Beaumont, 1985; Ascough et al., 2010; El Atfy et al., 2019). Thus, it seems rather unlikely that the observed shot-like holes were produced by microorganisms directly colonizing the charcoal. Based on this, it seems unlikely that the observed hyphae and filaments represent modern contamination.

The question remains: how can these decayrelated structures be compared to structures related to microbial decay in modern wood? Recently, El Atfy et al. (2019) provided a first general overview of pre-charring decay-related structures that can be observed in pre-Quaternary charcoal from clastic sediments. They interpreted the larger shot-like holes, with hyphae growing through them, as one type of evidence of brown rot, as such shot-like holes are considered to be more or less typical for this type of rot in modern plants (e.g. Daniel, 2003; Schweingruber et al., 2006; Schwarze, 2007). This kind of rot is usually caused by different interacting basidiomycetes, which selectively decay cellulose within cell walls (e.g. Schweingruber, 1990; Daniel, 2003; Schweingruber et al., 2006; Schwarze, 2007; Hiscox et al., 2018). However, this kind of rot is often accompanied by the formation of cell walls that are "wavy" as seen in cross-section, as the cell walls lose their stability due to the decay of cellulose and thus can be compressed easily after being affected by brown rot (e.g. Schweingruber, 1990; Daniel, 2003; Schweingruber et al., 2006; Schwarze, 2007). We did not observe this in the charcoal from Norken, so it is not certain that the shot-like holes can be used here as an indicator of brown rot; such holes can also be produced by other types of fungal wood-rot (cf. El Atfy et al., 2019 and references therein).

The small shot-like holes observed in some specimens resemble the effects of certain ascomycetes and/or tunnelling bacteria on cell walls of modern wood (e.g. Daniel, 2003; Singh et al., 2016). Based on their size, it seems possible that they were produced by the same organisms producing the filamentous structures we saw in some specimens. However, as no direct connection between these filaments and the small shot-like holes could be observed in the material from Norken, such an interpretation must remain speculative at the moment. It is, nevertheless, another clear indication of pre-charring decay seen in the charcoal from Norken.

Flat crater like-structures may be related to soft rot. In this kind of rot, microbes preferentially decay cellulose and hemicellulose, preferably in the secondary and/or tertiary cell walls of tracheids, ultimately leading to craters and, later on, large holes in the cell walls (e.g. Daniel, 2003; Schwarze, 2007). This type of precharring decay has previously been reported from Cretaceous charcoal (El Atfy et al., 2019). As stated above, these crater-like structures occur mostly in an area located between the phloem cells and normal tracheids with bordered pits. Thus, it seems possible that this kind of decay was restricted to, or started in, the area adjacent to the axial cambium.

Our observations indicate that several specimens of the charcoal from Norken experienced microbial decay prior to charring. The co-occurrence of charcoalified wood with indications of drying out prior to charring (checking of cell walls, cf. Jones, 1993) indicates that wildfire probably affected dead (and partly dried out) wood from litter or from partly dead but still standing trees; such a scenario would imply that the wood dried out after being attacked by microbes. Hollow and (at least) partly dead trees can be ignited rather easily when struck by lightning, producing large quantities of charcoal (e.g. Potonié, 1929; Scott 
et al., 2014). It seems likely that this charcoal should show traces of pre-charring decay, but actuo-taphonomic studies of such charred material are lacking, unfortunately. Other potential sources of charcoal with pre-charring traces of microbial decay are ground or surface fires, which might have charred partly decayed wood lying on the forest floor or even within peat (e.g. Uhl et al., 2019). A number of studies of various coals have indeed demonstrated that partly decayed plant material is frequently charred in peat and peat-forming vegetation (e.g. Guo and Bustin, 1998; Hower et al., 2011; Hower et al., 2013a,b,c). But again, actuo-taphonomic studies of such charred material are lacking.

From a taphonomical point of view, the three-dimensionally preserved hyphae are also of considerable interest. In almost all cases where fungal hyphae have been reported from pre-Quaternary charcoal, these hyphae were collapsed and probably fused to the cell walls (e.g. Uhl et al., 2007; Kubik et al., 2015; Jasper et al., 2017; El Atfy et al., 2019). In the specimens from Norken, transitions from threedimensionally preserved hyphae to collapsed hyphae can be observed. There are, however, no in-depth experimental studies dealing with the anatomical changes of fungal remains in modern charcoal originating from wood/plants affected by different types of rot/microbial decay. This lack of detailed (i.e. SEM) data hampers the interpretation of such remains in fossil charcoal, although it seems clear that many decay-related structures seen in fossil charcoal should be amenable to interpretation via direct comparisons with decay-related structures in modern uncharred wood (e.g. Moskal-del Hoyo et al., 2010; El Atfy et al., 2019).

The data from the Late Oligocene of Norken provide further evidence that pre-Quaternary charcoal can be used as an additional (so far largely underutilized) source for information about plant-microorganism interactions in deep time. They also point to a considerable gap in our knowledge about the taphonomy of microbial (i.e. fungal) remains in fossil charcoal: for example, three-dimensional preservation of hyphae (exceptional) versus collapsed hyphae (usual).

\section{ACKNOWLEDGEMENTS}

We thank M. Koziol (Maarmuseum Manderscheid, Germany) for loaning specimens from the Norken locality, C. Franz (Senckenberg Forschungsinstitut und Naturmuseum, Frankfurt, Germany) for technical assistance with SEM facilities, and Jakub Sakala (Prague) and two anonymous reviewers for their very valuable comments on an earlier draft of this manuscript. A. Jasper acknowledges financial support from the Conselho Nacional de Desenvolvimento Científico e Tecnológico (CNPq, Brazil - 19305436/2015-5) and the Alexander von Humboldt Foundation (Germany - 3.4-8151/18 025).

\section{REFERENCES}

Ascough, P.L., Bird, M.I., Scott, A.C., Collinson, M.E., Weiner, S., Cohen-Ofri, I., Snape, C.E., Le Manquais, K., 2010. Charcoal reflectance: implications for structural characterization. Journal of Archaeological Science 37, 1590-1599.

Baumann, H., 1993. Geologie des Westerwaldes in Schwerpunkten. In: Wegener, H.-H. (ed.), Der Westerwald. Kreis Altenkirchen und Westerwaldkreis, Stuttgart. [Theiss Verlag], 26, 13-21.

Beaumont, E., 1985. Industrial Charcoal Making. FAO Forestry Paper, vol. 63. Food and Agricultural Organization of the United Nations, Rome (http://www. fao.org/docrep/X5555E/x5555e00.htm\#Contents).

Daniel, G., 2003. 4. Microview of wood under degradation by bacteria and fungi. In: Godell, B. et al. (eds), Wood deterioration and preservation. ACS Symposium Series 2003, 34-72.

Degani-Schmidt, I., Guerra-Sommer, M., de Oliveira Mendonça, J., Mendonça Filho, J.G., Jasper, A., Cazzulo-Klepzig, M., Iannuzzi, R., 2015. Charcoalified logs as evidence of hypautochthonous/autochthonous wildfire events in a peat-forming environment from the Permian of southern Paraná Basin (Brazil). International Journal of Coal Geology 146, 55-67.

El Atfy, H., Havlik, P., Krüger, P.S., Manfroi, J., Jasper, A., Uhl, D., 2019. Pre-Quaternary wood decay 'caught in the act' by fire - Examples of plantmicrobe interactions preserved in charcoal from clastic sediments. Historical Biology 31, 952-961.

Gerards, T., Damblon, F., Wauthoz, B., Gerrienne, P., 2007. Comparison of cross-field pitting in fresh, dried and charcoalified softwoods. Iawa Journal 28, 49-60.

Guo, Y., Bustin, R.M., 1998. FTIR spectroscopy and reflectance of modern charcoals and fungal decayed woods: implications for studies of inertinite in coals. International Journal of Coal Geology 37, 29-53.

Hiscox, J., O'Leary, J., Boddy, L., 2018. Fungus wars: basidiomycete battles in wood decay. Studies in Mycology 89, 117-124.

Hower, J.C., O’Keefe, J.M.K., Eble, C.F., Raymond, A., Valentim, B., Volk, T.J., Richardson, A.R., Satterwhite, A.B., Hatch, R.S., Stucker, J.D., Watt M.A., 2011. Notes on the origin of inertinite macerals in coal: evidence for fungal and arthropod transformations of degraded macerals. International Journal of Coal Geology 86, 231-240.

Hower, J.C., Hoffman, G.K., Garrison, T.M., 2013a. Macrinite and funginite forms in cretaceous menefee formation anthracite, Cerrillos coalfield, New Mexico. International Journal of Coal Geology 114, 54-59. 
Hower, J.C., Misz-Keenan, M., O’Keefe, J.M.K., Mastalerz, M., Eble, C.F., Garrison, M., Johnston, M.N., Stucker, J.D., 2013b. Macrinite forms in Pennsylvanian coals. International Journal of Coal Geology 116-117, 172-181.

Hower, J.C., O'Keefe, J.M.K., Wagner, N.J., Dai, S., Wang, X., Xue, W., 2013c. An investigation of Wulantuga coal (Cretaceous, Inner Mongolia) macerals: paleopathology of faunal and fungal invasions into wood and the recognizable clues for their activity. International Journal of Coal Geology 114, 44-53.

Jasper, A., Agnihotri, D., Tewari, R., Spiekermann, R., Pires, E.F., da Rosa, Á.A.S., Uhl, D., 2017. Fires in the mire: repeated fire events in Early Permian 'peat forming' vegetation of India. Geological Journal 52, 955-569.

Jones, T.P., 1993. New morphological and chemical evidence for a wildfire origin for fusain from comparisons with modern charcoal. Special Papers in Palaeontology 49, 113-123.

Köhler, J., Uhl D., 2014. Die Blatt- und Karpoflora der oberoligozänen Fossillagerstätte Enspel (Westerwald, Rheinland-Pfalz, W-Deutschland). Mainzer naturwissenschaftliches Archiv, Beih. 35, 1-87.

Krüger, P., Paudayal, K., Wuttke, M., Uhl, D., 2017. Ein Beitrag zur oberoligozänen Makroflora von Norken (Westerwald, Rheinland-Pfalz, W-Deutschland). Mainzer naturwissenschaftliches Archiv 54, 65-81.

Kubik, R., Uhl, D., Marynowski, L., 2015. Evidence of wildfires during deposition of the Upper Silesian Keuper succession. Annales Societatis Geologorum Poloniae 85, 685-696.

Moskal-del Hoyo, M., Wachowiak, M., Blanchette, R.A., 2010. Preservation of fungi in archaeological charcoal. Journal of Archaeological Science 37, 2106-2116.

Müller, P., 1997. Fossillagerstätten im Westerwald. Westerburger Hefte 25, 54 pp.

Poschmann, M., Schindler, T., Uhl, D., 2010. Fossillagerstätte Enspel - a short review of current knowledge, the fossil association, and a bibliography. In: Wuttke, M., Uhl, D., Schindler, T. (eds), FossilLagerstätte Enspel - exceptional preservation in an Upper Oligocene maar. Palaeobiodiversity and Palaeoenvironments 90, 3-20.

Potonié, R., 1929. Spuren von Wald- und Moorbränden in Vergangenheit und Gegenwart. Jahrbuch des Preussischen geologischen Landesanstalt 49 (for 1928), 1184-1203.

Schäfer, P., Schindler, T., Hottenrott, M., Wuttke, M., 2011. 5.10. Westerwald. In: Deutsche Stratigraphische Kommission (eds), Stratigraphie von Deutschland IX - Tertiär, Teil 1: Oberrheingraben mit angrenzenden Teilbecken und Mittelgebirgen. Schriftenreihe der Deutschen Gesellschaft für Geowissenschaften 75, 416-435.

Schindler, T., Wuttke, M., 2010. Geology and limnology of the Enspel Formation (Chattian, Oligocene; Westerwald, Germany). In: Wuttke, M., Uhl, D., Schindler, T. (eds), Fossil-Lagerstätte Enspel exceptional preservation in an Upper Oligocene maar. Palaeobiodiversity and Palaeoenvironments 90, 21-27.

Schindler, T., Wuttke, M., 2015. A revised sedimentological model for the Late Oligocene Lake Enspel (Enspel Formation, Westerwald Mountains, Germany). Palaeobiodiversity and Palaeoenvironments 95, 5-16.

Schwarze, F.W.M.R., 2007. Wood decay under the microscope. Fungal Biology Reviews 21, 133-170.

Schweingruber, F.H., 1990. Mikroskopische Holzanatomie - Formenspektren mitteleuropäischer Stammund Zweighölzer zur Bestimmung von rezentem und subfossilem Material. 3rd ed. Birmensdorf: Eidg Forschungsanstalt für Wald, Schnee und Landschaft. 226 pp.

Schweingruber, F.H., Börner, A., Schulze, E.-D., 2006. Atlas of woody plant stems Evolution, structure, and environmental modifications. Berlin: SpringerVerlag. 229 pp.

Scott, A.C., 2000. The pre-quaternary history of fire. Palaeogeography, Palaeoclimatology, Palaeoecology 164, 281-329.

Scott, A.C., 2010. Charcoal recognition, taphonomy and uses in palaeoenvironmental analysis. Palaeogeography, Palaeoclimatology, Palaeoecology 291: 11-39.

Scott, A.C., Bowman, D.M.J.S., Bond, W.J., Pyne, S.J., Alexander, M.E., 2014. Fire on Earth: and introduction. Wiley Blackwell. 413 pp.

Singh, A.P., Kim, Y.S., Singh, T., 2016. Bacterial degradation of wood. In: Kim, Y.S., Funada, R., Singh, A.P. (eds), Secondary xylem biology. Academic Press, Cambridge, pp. 169-190.

Steckhan, W., 1973. Die Braunkohlen des Westerwaldes. Hessisches Lagerstättenarchiv 6, 1-114.

Uhl, D., Poschmann, M., 2018. Groenlandia pescheri sp. nov. (Potamogetonaceae) from the Late Oligocene Fossil-Lagerstätte Enspel (Westerwald, Germany). Acta Palaeobotanica 58, 61-72.

Uhl, D., Abu Hamad, A.M.B., Kerp, H., Bandel, K., 2007. Evidence for palaeowildfire in the Late Permian palaeotropics - charcoalified wood from the Um Irna Formation of Jordan. Review of Palaeobotany and Palynology 144, 221-230.

Uhl, D., Schindler, T., Wuttke, M., 2011. Paläoökologische Untersuchungen im Oberoligozän von Norken (Westerwald, Rheinland-Pfalz, W-Deutschland) - Erste Ergebnisse. Mainzer naturwissenschaftliches Archiv 48: 115-127.

Uhl, D., Krüger, P.S, Wuttke, M., 2018. Epidermal anatomy of Glyptostrobus europaeus (Brongniart) Unger from the Late Oligocene of the Westerwald (Rhineland-Palatinate, W-Germany). Fossil Imprint 75, 334-340.

Uhl, D., Jasper, A., Solorzano Kraemer, M.M., Wilde, V., 2019. Charred biota from an Early Cretaceous fissure fill in the Sauerland (RüthenKallenhardt, Northrhine-Westphalia, W-Germany) and their palaeoenvironmental implications. Neues Jahrbuch für Geologie und Paläontologie, Abh. 293(1), 83-105. 